BAJOPAS Volume 11 Number 2 December, 2018 http://dx.doi.org/10.4314/bajopas.v11i2.14

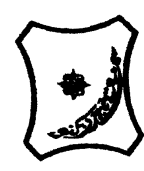

Bayero Journal of Pure and Applied Sciences, 11(2): 122 - 127

Received: February, 2018

Accepted: June, 2018

ISSN $2006-6996$

\title{
ASSESSMENT OF WATER QUALITY FOR SELECTED BOREHOLES AND SACHETS WATER IN MAIGATARI TOWN, JIGAWA STATE, NIGERIA
}

\author{
${ }^{* 182}$ Musa D. M., ${ }^{3}$ Garba Y. I., ${ }^{3}$ Yusuf M. S. and ${ }^{1}$ Ishaq A. \\ ${ }^{1}$ Department of Environmental Sciences, Federal University Dutse \\ ${ }^{2}$ Department of Geography, Bayero University Kano \\ ${ }^{3}$ Department of Environmental Management, Bayero University Kano \\ Corresponding Author: dahirumusa@fud.edu.ng (08028823540)
}

\begin{abstract}
Eight water samples were collected, four from different vendors of sachet water and four from different boreholes across Maigatari town. The samples were analyzed for $\mathrm{pH}$ using $\mathrm{pH}$ meter; Electrical Conductivity using a conductivity meter; while Turbidity of the water using turbidity meter. TDS and TSS using TDS meter. The electron microscope was used to determine the microbial counts. The results of the analysis revealed the range of values for the four (4) sachet and borehole waters respectively as $\mathrm{pH}(7-7.6)$ and $(6-6.3)$; Conductivity $(181-600)$ and $(413-998) \mu \mathrm{S} / \mathrm{m}$; Turbidity $(0-2)$ and $(1-2)$ NTU; Total Dissolve Solids (128 - 219) and (131 - 405) Mg/L; Total Suspended Solids $(62-85)$ and $(71-88) \mathrm{Mg} / \mathrm{L}$; Total Solids $(227-288)$ and $(215-476) \mathrm{Mg} / \mathrm{L}$; Microbes $(0-1)$ and $(0-3) \mathrm{cfu} / \mathrm{mL}$; Total Hardness $(41.5-111)$ and $(50.1-123.3) \mathrm{Mg} / \mathrm{L}$. The result also revealed strong positive correlation between $\mathrm{pH}$ and Conductivity (0.780); $\mathrm{pH}$ and TDS (0.875); pH and Microbes (1.046); turbidity and TS (0.906); Turbidity and Hardness (0.933); TS and Hardness (0.972) in sachet water. While Strong positive correlation existed between Conductivity and TDS (0.861); Conductivity and TSS (0.809); TDS and TSS (0.941) in borehole water. The water quality parameters analyzed were within the threshold of the Standard Organization of Nigeria (SON) with the exception of very few in one or the other samples. The parameters were significantly related to one another. It was however, recommended that the water vendors should improve the drinking water quality of their products and the officials of the Standard Organization of Nigeria (SON) should ensure strict adherence to regulations for drinking water quality.
\end{abstract}

Keywords: Borehole, Sachet, Quality, Water, Turbidity, Conductivity, Total Dissolve Solids.

\section{INTRODUCTION}

Water quality refers to the chemical, physical, biological and radiological characteristics of water (Kegley and Andrew,1998). It is a measure of the condition of water relative to the requirements of one or more biotic species and or to any human need or purpose (Goltman, 1978). Water is needed by all forms of life; man, animals, plants and even microorganisms. It is present in almost all part of the earth, about three quarter of the entire earth surface is made up of water and it exists in three states; vapour, liquid and solid (Kegley and Andrew,1998; Goltman, 1978). Groundwater from boreholes and shallow wells is a major source of drinking water in most rural areas of developing countries (Goltman, 1978). The quality of groundwater has been taken for granted. The status and potential threats of groundwater quality have not been investigated on a large scale in most of the developing countries (Moyo, 2013). Public health is at risk from physical and chemical contaminants in drinking water which may have immediate health consequences (Yousefi et al., 2017).

Good quality water is odorless, colorless, tasteless and free from fecal pollution. A reliable supply of clean healthy water is highly essential in a bid to promoting healthy living among the inhabitants of a defined geographical region. Safe and potable water supplies in urban areas in Nigeria are still inadequate in spite of several efforts from government. Drinking water in most rural communities of developing countries comes from sources such as rivers, streams, lakes, boreholes and wells; and they are likely to be polluted with domestic, agricultural or industrial wastes thus posing as potential health threat to consumer(Yakubuet al., 2010). There is dramatic increase in the consumption of sachet water, popularly known as "pure water" in Nigeria. Factory sachet water was introduced into the Nigerian market as an improvement on the hand-filled hand tied polythene-bagged type of vended water produced by the poor in Nigeria. Yakubuet al.(2010), lamented that, although the standard of hygiene in the various stages in the production of the factory sachet water may be higher compared to hand filled hand tied polythene-bagged water, bacteria are also thought to enter as contaminants during filling and sealing.

The standard industrialization world model for delivering of safe drinking water and sanitation technology is however, not affordable in most of the developing countries. Dada and Ntukekpo, (1997) reported that in Nigeria, about $80 \%$ of all diseases and over $30 \%$ of deaths were as a result of poor quality of drinking water. 
BAJOPAS Volume 11 Number 2 December, 2018

However, even in the developed countries where water quality has been significantly improved over the last decades as a result of new or improved treatment processes at the plants, the treated drinking water that enters a drinking water distribution system still contains particles, microorganisms, and nutrients (Liu et al., 2013; Proctor \& Hammes, 2015; Prest et al., 2016; Liuet al, 2017).Several studies on the quality of sachet water have reported violation of international quality standards. According to the Institute of Public Analysts of Nigeria (IPAN), $50 \%$ of the sachet water sold in the streets of Lagos may not be fit for consumption (Osibanjoet al; 2000;Sheshe, and Magashi, 2014).Sachets and borehole water are readily available and affordable, however, there are concerns regardingto its purity. The integrity of the hygienic environmental conditions of the sachet water vendors has been questioned. Apart from the environmental contaminants, contamination from improper vendor handling also poses threats to the health of the ignorant consumers. Therefore, water related diseases such as typhoid fever and cholera continued to be one of the major health problems globally(SON, 2000).

The National Agency for Food and Drug Administration and Control (NAFDAC) is mandated to enforce compliance with internationally defined drinking water guidelines, but regulation of the sachets and borehole water industry aimed at good quality assurance has remained a challenge to the agency. To control this menace of contaminated water in sachets and borehole water, NAFDAC declared a possible gradual nationwide ban on sachets water to allow manufacturers of sachets water to start winding down or change to bottle packaging(Olejeme, 2001). Successful implementation of this ban has remained far from reality as the sachets and borehole water market is witnessing tremendous growth especially among the poor and middle social classes. Pure water as it is popularly called is assumed to be of sufficient quality to serve as drinking water, treated and packaged in transparent polythene sachets with name, address of manufacturer, expiry date, NAFDAC number and logo boldly printed on it (Olejeme, 2001).Bore hole Water is required by almost all industries in the world for different purposes, some of which include; pharmaceutical preparation, soft-drink preparation, steam generation, ice making, tanning, fermentation and brewing(Kirk-Othmer, 1984). This paper, assessed the drinking water quality of some selected boreholes and sachets water in Maigataritown of Jigawa State, Nigeria with the aim to identify thresholds of some parameters associated with consumer complaints related to borehole and sachet waters in Maigatari town.

\section{MATERIAL AND METHODS \\ The Study Area}

Maigatari is located between latitude $12^{\circ} 23^{\prime} 00^{\prime \prime}-12^{\circ}$ $48^{\prime} 26^{\prime \prime} \mathrm{N}$ and longitude $9^{\circ} 27^{\prime} 05^{\prime \prime}-9^{\circ} 30^{\prime} 05^{\prime \prime} \mathrm{E}$. It is a border town between Nigeria and Niger Republic (Figure 1). Hence it is situated within the semi-arid region of the northern part of Nigeria. The scarcity of water resources in the area is a very important feature of semi-arid land.

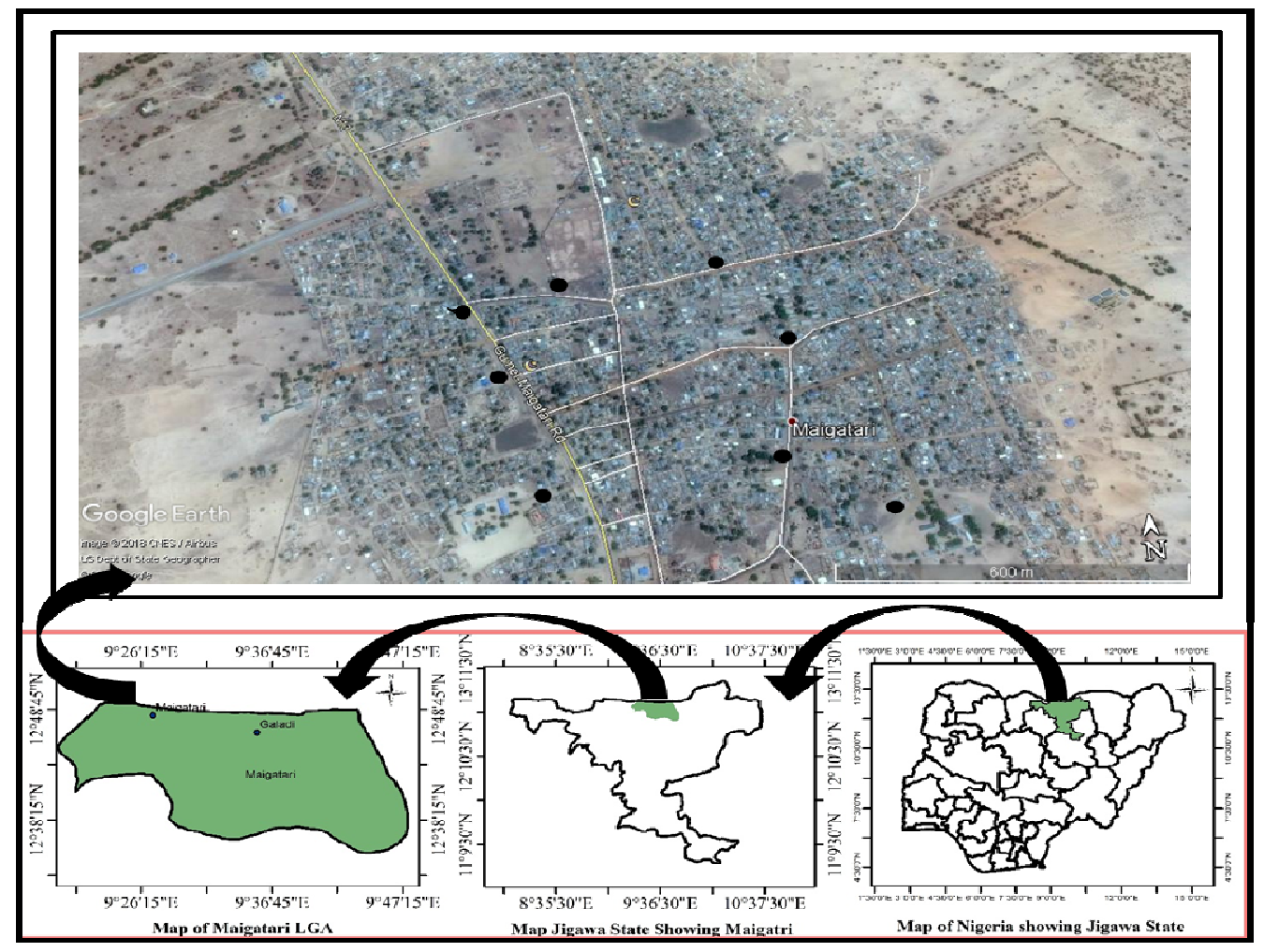

Figure 1. The Study Area showing the sampling points Source: Google Earth Map 
BAJOPAS Volume 11 Number 2 December, 2018

\section{Sampling Locations}

Eight water samples were collected for the study, four from different vendors of sachet water popularly called pure water which include sample A (Ma'ussaifi), sample B (Lautai Table Water), sample C (Garki Table Water) and sample D (Maizuma Table water) and four from different bore holes across Maigatari town which include sample A (GangarenKotu), sample B (Bakinkanti quarters), sample C (Jarma residence) and sample D (Kofar Fada).

The water samples from bore holes were collected in plastic containers, cover firmly and stored at a temperature below $4^{\circ} \mathrm{C}$ to prevent the growth of microorganisms. The samples were taken to Lab for the analysis of physicochemical parameters.

\section{Sample Analysis}

The $\mathrm{pH}$ of the water samples was determined by $\mathrm{pH}$ meter. Conductivity of the water samples was measured using a conductivity meter. While Turbidity of the water samples was determined using turbidity meter. Total Dissolved Solids (TDS), Total Suspended Solids (TSS) and Total Solids (TS) were estimated by summing up of TDS and TSS.TDS and TSS were measured using conductivity/TDS meter.The electron microscope was used to determine the microbial counts of the water samples. All the instruments were calibrated according to the manufacturer's specification. The analysis was conducted at Soil Lab, Federal University Dutse, Jigawa State, Nigeria.

\section{Data Analysis}

The data were statistically analyzed using descriptive analysis (minimum, maximum, mean and standard deviation) and correlation analysis to see significant relationships between the water quality parameters. The results obtained were also compare with the threshold for the Standard Organization of Nigeria (SON).

\section{RESULTS AND DISCUSSION}

The results of the analysis for the sachet and borehole water are presented in Table 1 and 2 respectively. The result of the sachet water indicated that $\mathrm{pH}$ value ranged from $7-7.6$ with an average of 7.4 and standard deviation of 0.3 (Table 1 ). While the
$\mathrm{pH}$ value of the borehole water ranged from $6-6.3$ with an average of 6.1and standard deviation of 0.1 (Table 2).This implies that the $\mathrm{pH}$ of the water in the area is within the permissible limit of the Standard Organization of Nigeria (SON). In a related research conducted by Jidauna et al., (2017) from Dutsima, Katsina State, found pH value of 7.29 in Sachet water and 6.95 in Borehole water. However, $\mathrm{pH}$ values of 6.8 and 6.4 (wet and dry seasons respectively) were detected in Sachet water from Katsina Metropolis (Rumaet al., 2014).

Conductivity is a measure of the ability of water to pass an electrical current. Conductivity in water is affected by the presence of inorganic dissolved solids such as chloride, nitrate, sulfate, and phosphate anions (ions that carry a negative charge) or sodium, magnesium, calcium, iron, and Aluminium cations (ions that carry a positive charge).The conductivity of the sachet water ranged from $181-600 \mu \mathrm{S} / \mathrm{m}$ with mean value of $350.3 \mu \mathrm{S} / \mathrm{m}$ and the SD of 198.7 $\mu \mathrm{S} / \mathrm{m}$ (Table 1 ). While the conductivity of borehole water ranged from $413-998 \mu \mathrm{S} / \mathrm{m}$ with the mean value of $591.5 \mu \mathrm{S} / \mathrm{m}$ and SD of $274.1 \mu \mathrm{S} / \mathrm{m}$ (Table 2). This implies that the conductivity values are within the permissible limit of the SON except water sample C (Table 2) which is almost at the threshold. The high conductivity level of sample $C$ could be linked to higher concentration of inorganic materials as the sampling point is close to the market, motor park, motor mechanics which result in the discharge of different kind of effluents and sewage to the soil which subsequently leached down to ground water. High level of Electrical Conductivity of $774.50 \mu \mathrm{S} / \mathrm{mwas}$ detected in Borehole water while $126.25 \mu \mathrm{S} /$ mwas detected in sachet water at Dutsima (Jidauna et al., 2017). However, lower conductivity of $38.70 \mu \mathrm{S} / \mathrm{m}$, $30.20 \mu \mathrm{S} / \mathrm{m}$ and $38.8 \mu \mathrm{S} / \mathrm{m}$ were respectively detected in water at Dass, Kaltungo and Langtang towns that have cases of stained and mottled teeth in Nigeria (Ezeribe et al., 2012). Ruma et al., (2014) detected moderate Electrical Conductivity of 145.2 $\mu \mathrm{S} / \mathrm{m}$ and $161.1 \mu \mathrm{S} / \mathrm{m}$ during wet and dry seasons respectively in sachet water at Katsina, Nigeria.

Table 1. Summary of Statistics for Water Quality Parameters in the Sachet Water

\begin{tabular}{llllll}
\hline Parameters & Min. & Max. & Mean & SD & SON \\
\hline pH & 7 & 7.6 & 7.4 & 0.3 & $6-9$ \\
Conductivity $(\mu \mathrm{S} / \mathrm{m})$ & 181 & 600 & 350 & 198.7 & $500-1000$ \\
Turbidity(NTU) & 0 & 2 & 1 & 0.8 & $1-25$ \\
TDS(Mg/L) & 128 & 219 & 190 & 30.4 & 500 \\
TSS $(\mathrm{Mg} / \mathrm{L})$ & 62 & 85 & 77 & 10.3 & 100 \\
TS $(\mathrm{Mg} / \mathrm{L})$ & 227 & 288 & 267 & 27.5 & 500 \\
Microbe(cfu/mL) & 0 & 1 & 0.3 & 0.5 & 500 \\
Total Hardness(Mg/L) & 41.5 & 111 & 82 & 30.4 & 100 \\
\hline
\end{tabular}

The turbidity of water is the measure of relative clarity of water. Turbidity describes the cloudiness of water caused by suspended particles such as clay and silts, chemical precipitates such as manganese and iron, and organic particles such as plant debris and organisms (APHA/AWWA/WEF, 2012; GCDWQ, 2012). As turbidity increases, it reduces the clarity of water to transmitted light by causing light to be scattered and adsorbed. 
Table 2. Summary of Statistics for Water Quality Parameters in Borehole Water

\begin{tabular}{llllll}
\hline Parameters & Min. & Max. & Mean & SD & SON \\
\hline pH & 6 & 6.3 & 6.2 & 0.1 & $6-9$ \\
Conductivity $(\mu \mathrm{S} / \mathrm{m})$ & 413 & 998 & 591.5 & 274.1 & $500-1000$ \\
Turbidity(NTU) & 1 & 2 & 1.8 & 0.5 & $1-25$ \\
TDS $(\mathrm{Mg} / \mathrm{L})$ & 131 & 405 & 261.8 & 117.8 & 500 \\
TSS(Mg/L) & 71 & 88 & 78.5 & 8.8 & 100 \\
TS(Mg/L) & 215 & 476 & 340.3 & 110.7 & 500 \\
Microbe(cfu/mL) & 0 & 3 & 1.3 & 1.5 & 500 \\
Total Hardness(Mg/L) & 50.1 & 123.3 & 87.6 & 31.1 & 100 \\
\hline
\end{tabular}

The turbidity of the sachet water ranged from $0-2$ NTU with the average value of 1 NTU and SD of 0.8 NTU (Table 1). While the turbidity of borehole water ranged from $1-2$ NTU with mean value of 1.8 NTU and SD of 0.5 NTU (Table 2). This indicates that the turbidity of the water in the study area is within the permissible limit of the Standard Organization of Nigeria (SON).It also implies that the turbidity of the sampled water is invisible by the naked eye because turbidities below 4 NTU can only be detected by instruments; however, at 4 NTU and above, a milkywhite,muddy, red-brown or black suspension can be visible and can reduce the acceptability of drinking water(WHO, 2017). Strong correlation exists between turbidity and total solid (0.906) and between turbidity and the hardness (0.933) in the sampled sachet water(Table 3)and also between turbidity and total suspended solids (0.567)(Table 4). This implies that as total solid in water increases, the turbidity of water also increases. This is in agreement with WHO (2017) which stated that turbidity of water affects the water hardness more especially when the source of turbidity is inorganic particles released by weathering of rocks, soils and clays.

Table 3. Correlation Matrixfor Water Quality Parameters in Sachet Water

\begin{tabular}{lllllllll}
\hline & $\mathrm{pH}$ & Cond. & Turb. & TDS & TSS & TS & Microbe & Hardness \\
\hline $\mathrm{pH}$ & 1 & & & & & & & \\
Conductivity & 0.780 & 1 & & & & & & \\
Turbidity & -0.866 & -0.491 & 1 & & & & & \\
TDS & 0.875 & 0.683 & -0.563 & 1 & & & & \\
TSS & -0.206 & 0.372 & 0.237 & -0.410 & 1 & & & \\
TS & -0.660 & -0.439 & 0.906 & -0.221 & -0.114 & 1 & & \\
Microbes & 1.046 & -0.504 & 0 & 0.285 & -0.971 & 0.339 & 1 & \\
Hardness & -0.801 & -0.628 & 0.933 & -0.413 & -0.125 & 0.972 & 0.357 & 1 \\
\hline
\end{tabular}

The Total Dissolved Solids (TDS) of water are the particles that are smaller than $2 \mu$ found in the water column. The total dissolve solids of the sachet water ranged from $128-219 \mathrm{mg} / \mathrm{L}$ with an average of 190 $\mathrm{mg} / \mathrm{L}$ and SD of $30.4 \mathrm{mg} / \mathrm{L}$ (Table 1 ). While the value of total dissolve solid of the borehole water ranged from $131-405 \mathrm{mg} / \mathrm{L}$ with mean value of $261.8 \mathrm{mg} / \mathrm{L}$ and SD of $117.8 \mathrm{mg} / \mathrm{L}($ Table 2). This implies that even though the total dissolved solid of the water in the area is within the range of the Standard Organization of Nigeria (SON), the sachet water sampled underwent certain purification methods. While the borehole water sample did not received treatment. This is evident from sample $C$ which is close to the threshold. TDS show strong correlation with TSS (0.941) indicating that an increase in TSS may result to increase in TDS. However, in a related study by This indicates that the total suspended solids of the sampled water are within the permissible limit of the Standard Organization of Nigeria (SON). However, the total suspended solids in the borehole water is close to the threshold especially sample C. Strong correlation exists between total suspended solids and total dissolve solids (0.941) and between total suspended solids and conductivity (0.809) of the
Alexandraet al., (2017) from Ghana, found that the concentration of TDS in water samples to be above $172 \mathrm{mg} /$ Land were associated with salty taste.

The total suspended solids of water are the particles that are larger than $2 \mu$ found in the water column. These are solids in water that can be trapped by a filter. TSS can include a wide variety of material, such as silt, decaying plant and animal matter, industrial waste and sewage. High concentration of suspended solids in drinking water can cause many problems(Murphy, 2017). The total suspended solids for the sachet water ranged from $62-85 \mathrm{mg} / \mathrm{L}$ with the mean value of $77 \mathrm{mg} / \mathrm{L}$ and SD of 10.3 $\mathrm{mg} / \mathrm{L}($ Table 1$)$. While the total dissolve solids for the borehole water ranged from $71-88 \mathrm{mg} / \mathrm{L}$ with an average value of $78.5 \mathrm{mg} / \mathrm{L}$ and SD of $8.8 \mathrm{mg} / \mathrm{L}$ (Table 2).

water in the sampled borehole water(Table 4). However, there exists wick correlation between total suspended solids and conductivity (0.372), and also turbidity (0.237) of the sampled sachet water(Table 3 ). This is still indicating that the sampled sachet water had been processes for consumption in the area. 
BAJOPAS Volume 11 Number 2 December, 2018

Table 4. Correlation Matrix for Water Quality Parameters in the Borehole Water

\begin{tabular}{|c|c|c|c|c|c|c|c|c|}
\hline & $\mathrm{pH}$ & Cond. & Turb. & TDS & TSS & TS & Microbe & Hardness \\
\hline $\mathrm{pH}$ & 1 & & & & & & & \\
\hline Conductivity & -0.737 & 1 & & & & & & \\
\hline Turbidity & -0.927 & 0.434 & 1 & & & & & \\
\hline TDS & -0.550 & 0.861 & 0.287 & 1 & & & & \\
\hline TSS & -0.736 & 0.809 & 0.567 & 0.941 & 1 & & & \\
\hline TS & 0.102 & -0.725 & 0.248 & -0.828 & -0.590 & 1 & & \\
\hline Microbes & 0.485 & -0.648 & -0.333 & -0.931 & -0.945 & 0.651 & 1 & \\
\hline Hardness & 0.690 & -0.351 & -0.764 & -0.557 & -0.792 & 0.014 & 0.755 & 1 \\
\hline
\end{tabular}

The total solid of water refers to all solid matter that are either suspended or dissolve in water. The total solids for the sachet water sampled ranged from 227 $-288 \mathrm{mg} / \mathrm{L}$ with mean value of $267 \mathrm{mg} / \mathrm{L}$ and SD of $27.5 \mathrm{mg} / \mathrm{L}$ (Table 1 ). While the total solids of the sampled borehole water ranged from $215-478 \mathrm{mg} / \mathrm{L}$ with an average value of $340.3 \mathrm{mg} / \mathrm{L}$ and SD of 110.7 $\mathrm{mg} / \mathrm{L}$ (Table 2). This indicates that the total solids of the sampled water from the study area is within the permissible limit of the Standard Organization of Nigeria (SON, 2000).Strong correlation exists between total solids and water hardness (0.972) in(Table 3)and between the total solids and microbes (0.651) in(Table 4). This implies that any increase in total solids of water will affects both the hardness and microbial candidates of sampled water depending on the nature and source of the solids.

The fecal coliform is an indicator of microorganisms 'presence in water sample. It indicates the presence of other pathogenic bacteria, diseases and illnesses that can be contracted in wate $r$ (Kegley and Andrew, 1998). The microbial counts of the sampled sachets water ranged from $0-1 \mathrm{cfu} / \mathrm{mL}$ with the mean value of $0.3 \mathrm{cfu} / \mathrm{mL}$ and SD of $0.5 \mathrm{cfu} / \mathrm{mL}($ Table 1$)$. While the microbial counts of the sampled borehole water ranged from $0-3 \mathrm{cfu} / \mathrm{mL}$ with the average value of $1.3 \mathrm{cfu} / \mathrm{mL}$ and SD of $1.5 \mathrm{cfu} / \mathrm{mL}$ (Table 2). This indicates that the microbial counts in the sampled water is within the permissible limit of the Standard Organization of Nigeria (SON). Result shows very strong positive relationship between microbes and $\mathrm{pH}$ (1.046) in (Table 3)and between microbes and total solids (0.651) in (Table 1 ). This signifies that since the $\mathrm{pH}$ is within $7-7.4$ in the case of sampled sachet water(Table 1), the condition is unfavourable for the growth of microbes and therefore, the sampled sachet water is more or less free from microbes. However, in the case of sampled borehole water, strong positive correlation exists between microbes and total solids $(0.651)$ (Table 4$)$, this might be the slightly acidity $(\mathrm{pH}: 6-6.3)$ in (Table 2)which may favoured the growth of certain microbes in the sampled borehole water.

Water hardness is the measure of polyvalent cations (ions with a charge greater than +1 ) in water. Water with high hardness values is regarded as hard while one with low hardness values is regarded as soft. Hardness affect the amount of soap required to produce good lather or form. Hard water requires more soap than soft water. Water with a total hardness in the range of $0-60 \mathrm{mg} / \mathrm{Lis}$ termed soft; 61- $120 \mathrm{mg} / \mathrm{L}$ moderately hard; $121-180 \mathrm{mg} / \mathrm{L}$ hard; and above $180 \mathrm{mg} / \mathrm{L}$ very hard (WHO, 2011; McGowan, 2000). The hardness of the sampled sachet water ranged from 41.5 - $111 \mathrm{mg} / \mathrm{L}$ with the mean value of $82 \mathrm{mg} / \mathrm{L}$ and SD of $30.4 \mathrm{mg} / \mathrm{L}$ (Table 1 ). While hardness of the sampled borehole water ranged from $50.1-123.3 \mathrm{Mg} / \mathrm{L}$ with an average of $87.6 \mathrm{mg} / \mathrm{L}$ and SD of $31.1 \mathrm{mg} / \mathrm{L}($ Table 2$)$. This indicates that the sampled waters are within the standard limit for drinking water quality. In similar study conducted by Moyo (2013) in Zimbabwe, found the concentration value of $2550 \mathrm{mg} / \mathrm{L}$ in a borehole at Gwayi catchment area. However, sampled C and B in sachet and borehole water respectively exceed the permissible limit of the Standard Organization of Nigeria (SON) while water sample $D$ in both sachet and borehole water are closed to the threshold. On the other way, sample $A$ in both sachet and borehole water are soft water. Water samples B, C, D and C, D in sachet and borehole respectively are moderately hard. While water sample B in borehole is hard.

Strong positive correlation exists between water hardness and turbidity (0.933) and water hardness and total solids (0.972) in sampled sachet water(Table 3); and also, between water hardness and microbe (0.755) and water hardness and $\mathrm{pH}$ (0.690) in sampled borehole water (Table 4). This implies that hardness of water is affected by turbidity, total solids and $\mathrm{pH}$.

\section{CONCLUSION}

Based on the result obtained, the water quality parameters analyzed for the sampled water are within the threshold of the Standard Organization of Nigeria (SON) except the total hardness in sample $D$ for sachet water and sample B for borehole water. The analyzed water quality parameters are significantly related to one another. However, the relationship varies between the parameters but strong positive relationship dominates. The study recommended that the sachet water vendors should improve the drinking water quality of their products and the officials of Standard Organization of Nigeria should ensure strict adherence to regulations for drinking water quality.

\section{Conflict of Interest}

The author declare no conflict of interest. 


\section{REFERENCES}

Alexandra, V. K., Jeanine, D. P., Kenneth, K.H. C., Karen, C. K. \& Elena, N. N. (2017). Physicochemical parameters affecting the perception of borehole water quality in Ghana. International Journal of Hygiene and Environmental Health, 220(6), 990-997.

APHA/AWWA/WEF. (2012). Standard method 2130: turbidity. Standard methods for the examination of water and wastewater (22nd ed.). Washington, DC: American Public Health Association, American Water Works Association and Water Environment Federation.

Dada, A. and Ntukekpo, S. (1997). Pure water; How safe? Ultimate water technology and Environment, 1-5.

Ezeribe, A. I., Oshieke, K. C. \& Jauro, A. (2012). Physicochemical Propertises of Well water samples from some Villages in Nigeria with cases of Staine and Mottle Teeth. Science World Journal, 71$), 1-3$.

GCDWQ. (2012). Guidelines for Canadian drinking water quality: guideline technical document - turbidity. Water, Air and Climate Change. Ottawa, Ontario: Bureau, Healthy Environments and Consumer Safety Branch,. Retrieved from www.hc-sc.gc.ca/ewhsemt/pubs/water-eau/turbidity/indexeng.php

Golteman, H. L. (1978). Methods for Physical and Chemical Analysis of Fresh Waters. USA: Billing and Sons Ltd.

Jidauna, G.G., Barde, S.R., Ndabula, C., Oche, C.Y., \& Dabi, D.D. (2017). Water quality assessment of selected domestic Water sources in Dutsinma town, Katsina State. Science World Journal, 12(4), 43-50.

Kegley, E.S. and Andrew, J. (1998). The Chemistry of Water. Chemical Parameters for Water Quality (2nd ed.). California: University Science Books.

Kirk-Othmer. (1984). Drinking Water Quality. NY: John Willey and Sons.Inc.

Liu, G., Ling, F., Magic-Knezev, A., Liu, W., Verberk, J. Q. J. C., Van Dijk, J. C. (2013). Quantification and identification of particle associated bacteria in unchlorinated drinking water from three treatment plants by cultivation independent methods. Journal of Water Resource, 4Х10), 3523-3533.

Liu, G., Tao, Y., Zhang, Y., Lut, M., Knibbe, W.J., Wielen, P. V., Liu, W., Medema, G. \& Meer, W. V. (2017). Hotspots for selected metal elements and microbes accumulation and the corresponding water quality deterioration potential in an unchlorinated drinking water distribution system. Journal of Water Resource, 124 (2017), 435-445.

McGowan, W. (2000). Water processing: residential, commercial, light-industrial (3rd ed.). Lisle IL: Water Quality Association.
Moyo, N. (2013). An analysis of the chemical and microbiological quality of ground water from boreholes and shallow wells in Zimbabwe. Journal of Physics and Chemistry of the Earth, 66(A/B/C ), 27-32.

Murphy, S. (2017). BASIN. Retrieved from BASIN: General Information on Total Suspended Solids: www.ben.boulder.co.us

Olejeme, C. (. (2001). Health Implication of Drinking Contaminated Water, A lecture Delivered at Fed. Poly Damaturu Nigeria during the Workshop on Packaged (Table) Water and water based drink. Damaturu: NAFDAC.

Osibanjo, O., Ajayi, S., Adebiyi, F. \& Akinyanju, P. . (2000). Public Analysis Reporting System as Applied to Environmental Issues. IPAN News. Insitute of Public Analysts, 1(3), 10.

Prest, E.I., Hammes, F., van Loosdrecht, M.C., Vrouwenvelder, J.S., . (2016). Biological stability of drinking water: controlling factors, methods, and challenges. Journal of Frontier Microbiology, 1-7.

Proctor, C.R., \& Hammes, F. (2015). Drinking water microbiology from measurement to management. Journal of Current Opion Biotechnology, 33, 87-94.

Ruma, M.M., Badr, A.M.A., Khater, S.A.A. \& Eltantawi, A.M.M. (2014). Assessment of some physicochemical Parameters levels in some sachets drinking Water and its effects on Human Health in Katsina Urban Area, Nigeria. Science World Journal Vol 9 (No 1) 2014, 9(1), 19-27.

Sheshe, M. U. \& Magashi, A. M. (2014). Assessment of physicochemical quality of sachet water produced in selected local government areas of Kano Metropolis, Kano State, Nigeria. Bayero Journal of Pure and Applied Sciences, $72), 31-35$.

SON. (2000). Safe Drinking Water Regulation. Abuja: Standard Organization of Nigeria.

WHO. (2011). Hardness in Drinking-water. Background document for development of WHO Guidelines for Drinking-water. Geneva: WHO Press.

WHO. (2017). Water Quality and Health- Review of Turbidity, Information for regulators and water suppliers. WHO.

Yakubu, B. N., Adebukola, A. S., Siyeofori M. F., Geoffrey, A. A. \& Tamunobelema, O. I. (2010). Bacteriological safety of plasticbagged sachet drinking water sold in Amassoma, Nigeria. Asian Pacific Journal of Tropical Medicine, 555-559.

Yousefi, M. Saleh, H. N., Mohammadi, A. A., Mahvi, A. H., Ghadrpoori, M. \& Suleimami, H. (2017). Data on water quality index for the groundwater in rural area Neyshabur County, Razavi province, Iran. Journal of Data in Brief 15 (2017), 15(2017), 901-907. 